\title{
PROPOSING AWOAF ALTERNATIVE PLAN (AAP): THE WAY FORWARD \& SUSTAINABLE HIGHER EDUCATION FINANCIAL SYSTEM
}

\author{
Anwar Allah Pitchay ${ }^{1}$, Mohd Najwadi Yusoff Abdul Rahman ${ }^{2}$, \\ Mohamed Asmy Mohd Thas Thaker ${ }^{3}$, Zubir Azhar ${ }^{4}$, Al Amin Mydin ${ }^{5}$, \\ Mohamad I'sa Abd Jalil ${ }^{6}$
}

\begin{abstract}
The future direction of the public university is to self-sustained due to the inconsistency of the national economic growth. For example, reduced in the national income has forced the Malaysian government to cut the allocation of funds to various ministries' in 2016 compared to 2015 budget. The consequences of this phenomenon the government has reduced the allocation of budget to Ministry of Higher Education, which is cut by RM2.4 billion, from RM15.78 billion in 2015 compared to RM13.37 billion in 2016. This scenario has imposed various challenges to many public universities' management to manage university expenses and explore new avenue to generate income. There are various ways to generate income and we find most of the tertiary education in Malaysia is not able to practice effective management especially in managing the cost of organizing a program. For example, food and beverages (F\&B) spend by the university during events are not effective and most of the time is wasted.

This argument is developed based on the observation and also supported by an informal interview with a vice-chancellor (VC) of one of the public university in Malaysia. The VC do agree that the university management needs to find a solution to overcome the issue of wastage due to the forecasted cost rather than an accurate cost to organize a university's events. Therefore, we believe that the main issue faced the university's management is to identify an exact number of participants and etc. Thus, the current practice is based on the forecasted estimation rather than accurate estimation. Therefore, to solve this problem, the present study aims to provide an opportunity to the tertiary education in Malaysia which able to estimate an accurate cost and at the same time able to create waqf fund using effective fund management approach by proposing awqaf alternative plan (AAP) model. The proposed model is expected to generate Waqf fund and eliminate wastage management practice.
\end{abstract}

Keywords: Waqf, Higher Education and Awqaf Alternative Plan (AAP) model

\footnotetext{
${ }^{1}$ Universiti Sains Malaysia, anwar@usm.my

2 Universiti Sains Malaysia, najwadi@usm.my

${ }^{3}$ International Islamic University Malaysia, asmy@iium.edu.my

${ }^{4}$ Universiti Sains Malaysia, zubirazhar@usm.my

${ }^{5}$ Universiti Sains Malaysia, alamin@usm.my

${ }^{6}$ University Malaysia Sabah, isa@ums.edu.my
} 


\section{INTRODUCTION}

The tertiary education is a catalyst for the birth of experts and scientists. Therefore, the role of higher education institutions is very important in creating a first-class human capital. The $10^{\text {th }}$ Malaysian Plan has provided an opportunity for local universities to gain autonomy in stages. Through this autonomy, each university will have the power and the right to earn money and managed their university independently. Granting autonomy to each university is expected to strengthen their role and enhance the performance of institutions and a culture of healthy competition, and at the same time, it will be monitored by the government to ensure the quality and goals in line with the creation of the university foundation. Besides the vision of the government plan, there are many factors or risks that may influence the implementation of a policy.

Unsystematic risk factors such as the oil prices fluctuation have in 2015 has affected most of the oil producing countries to estimate their national budget for the year 2016. Malaysia is one of the oil-producing countries that faced high deficit budget due to the unstable pricing of oil and other domestic challenges. Reduced in the national income has forced the Malaysian government to cut the allocation of funds to various ministries' in 2016 compared to 2015 budget. The consequences of this phenomenon, the government has reduced the allocation of budget to Ministry of Higher Education, which is cut by RM2.4 billion, from RM15.78 billion in 2015 compared to RM13.37 billion in 2016. This scenario has imposed various challenges to public universities' management to manage university expenses and explore new avenue to generate income. Currently, the long-term financial sustainability of local universities are the fundamental issues for the education providers. The modern concept of the financial assistance such as debt (borrowing), increasing students' fee may not be a solution in the long run. We strongly believe that modern types of financial instruments should not be always become the priority for the policymakers. This is because the reputable and long-established universities such as Al-Azhar, Harvard and Oxford are basically depending on the endowment funds. This fund is based on the concept of charity which the public donate assets to finance various public infrastructure such as universities, hospitals, highways, etc.

Endowment fund or in Islamic epistemology is known as waqf is not new to any Muslim countries like Malaysia. We can find most of the private school in Malaysia are funded using waqf and we strongly believe that this similar concept of financing can be applied to tertiary level. There are numerous ways to generate income or focus on reducing expenses through prudent management practised. 
Based on the observation, we find that tertiary education in Malaysia is not able to practice effective management practice. For example, food and beverages (F\&B) which spend by the university during events are not effective and most of the time is a waste. This argument is developed based on the observation and based on an informal interview with a vice-chancellor (VC) of one of the local university. The $\mathrm{VC}$ do agree that the university management needs a solution to overcome the issue of wastage, especially during big events. We believe that the main issue faced the university's management is to identify an exact number of participants to place an order for food. Thus, the current practised is based on the forecast estimation rather than accurate estimation. Therefore, to solve this problem, the present study aims to provide an opportunity to the tertiary education in Malaysia able to estimate an accurate cost and at the same time able to create waqf fund using effective fund management approach by proposing awqaf alternative plan (AAP) model.

\section{LITERATURE REVIEW}

This chapter reviews past studies of waqf development. Review of past study is divided into three parts: (1) first period which reviewed on Islamic law and Islamic studies; (2) second period which reviewed on a case study on historical of Waqf establishment; and (3) third period reviewed on management issue until present day of the Waqf studies. Next section focuses on the existing waqf project development in the past and present over the world.

Waqf system has the cover broader scope of contribution to the society in past especially to the development of religious activities and enhancing the society standard of living. The main aim of the Waqf system is to eradicate the poverty in society through improving in term of social and economic. Past studies have covered several areas, in which the present study becomes part of the evolution. Hoexter M. (1998) classifies Waqf study into 3 periods; the first period covers up to the early 1950s, the second periods cover from 1950s till late 1980s and the third period covers from 1990s to, arguably, the present day.

\subsection{First Period: Islamic Law \& Islamic Studies}

The first period of the waqf studies was generally focused on the legal issue. For example, the issues were concerning about the question of waqf condition, types of waqf, the characteristic of waqf, the legal rules and motive of waqf from religious aspect (Hoexter M., 1998). Most of the researchers carried out their research based on the viewpoint of Islamic law (Syariah), which justify the concern about the rule and condition of Waqf by using Qur'an and Hadeeth. However, 
these matters were not clearly stipulated in both main sources. Hence during the first period, the researchers were focused on addressing waqf issues by interpreting and issuing religious decrees that dealing with current problems regarding waqf.

\subsection{Second Period: Case Study on Historical of Waqf Establishment}

In the second period, the research area in waqf becomes more widen. But, the researchers still carried out the study from the perspective of Islamic law especially focused on a specific waqf establishment. This included analysis of waqf deeds documents. The study of specific waqf establishment comprises of investigation on the impact of waqf toward the society at the time. The research landmark in this period was the organization of an international Islamic seminar in Jerusalem in June 1979. Hoexter M. (1998) says that the seminar was the first international gathering specifically discussed waqf. The seminar discussed many issues that related to waqf. Among the issues that discussed were,

".....the economic implications of the waqf; its significance for the various public services; the Waqf and the law of succession; the impact of the endowment on the social system; the relationship between waqf and state" (Hoexter M., 1998, p.475).

The above comment by Hoexter M. (1998) shows that the discussion of Waqf in the second period has started to give more attention to economic implication and the future direction of Waqf. Furthermore, discussion on research methodology also initiated, and the seminar, at later date, was credited with the introduction of a new branch of study, i.e. waqf Studies (Hoexter M, 1998). This period basically addresses the understanding of Waqf especially during its golden age of Islam in past. This is important because of the first period of the study, where the emphasis is only on the legal issue. Hoexter M. (1998, p.475) noted that,

"What today is common knowledge, that prior to the twentieth century a broad spectrum of what we now designate as public or municipal services, e.g. welfare, education, religious services, construction and maintenance of the water system, hospitals, etc. were set up, financed and maintained almost exclusively by endowments, was documented in this stage".

The above passage highlights Waqf contribution to society and economy during the second period of waqf studies. While, the first period was focusing on legal aspect and then a discussion on management and financial aspect began to take shape slowly, although mainly were from the historical perspective (Hoexter M., 
1998). For example, the management of Waqf properties was studied, which addresses the issue of management negligent and available court records dealing with these cases (Hoexter M., 1998).

\subsection{Third Period: Management Studies}

The third period begins in the early 1990s and reaches the present day. Hoexter M. (1998) says that third-period studies were basically discussed during the first two periods and some current development, which the third period "may be discerned in the study of Islamic endowment institution". She provides some examples such as,

"Waqf and the idea of charity, a comparison of the Islamic endowment institution in other cultures, the dynamics of Islamic law as reflected in the Waqf, the concepts of private and public in the Waqf in the formation of civil society and public sphere" (Hoexter M., 1998).

This period, most of the waqf studies focusing on a country-based experience. The research focused on the reason for its decline in importance and the problem afflicting the traditional practice of Waqf management and potential solution. Hoexter M. (1998) has provided detailed information on Waqf studies. The next paragraph continues with the strand of management literature in the third period, which specifically focused on the mode of financing. This will provide better information especially to find the research gap that exists in this particular issue.

\subsubsection{Continuous Of Past Studies In Third Period}

The previous section has provided a brief discussion about the scope of researches covered in Waqf studies. The areas of Waqf studies become wider especially during the third period and there are many issues discussed by past researchers with the aim to revive the role of Waqf system in present day. There are many past studies conducted which attempt to solve the problem of idle Waqf land in Malaysia and other countries. So far, there are no empirical studies attempt to propose Islamic organization and institutions and Muslim employees to be the respondents to contribute cash Waqf for the development of Waqf based projects in Malaysia.

Ibdal and Istibdal (exchange and substitution) are the two first modes of developing the idle Waqf land (Kahf M., 1998; Mohammad, 2008; Sabit, 2009). However, this mode faced approval problem from a jurist of different thoughts of school, which generated a subject of divergence of views among scholars. 
Furthermore, there are many cases of fraud occurred during the process of Ibdal and Istibdal (Kahf M., 1998; Sabit, 2009). Other traditional modes are Hikr (long lease with large advance lump sum) and ljarah (lease with dual payment) are used for the renovation of the Waqf properties (Sabit, 2009). However, these two modes have shortcomings in term of the involvement of sacrifice of the assets in which the lessee has perpetual staying right on Waqf assets. Furthermore, it may subject to fraud and corruption particularly in term of the use of profit generated from the selling of the long lease rights (Kahf M., 1998). There is also number debt-based instrument that introduced for financing the development of Waqf properties such as Murabahah and Salam. These modes, the manager borrow to develop the property and the amount owed to the financing company will be settled from the revenue that generated from Waqf project (Sabit, 2006). However, the disadvantage of these modes, they expose the Waqf property to high risk which might result in confiscation and auction of the property of Waqf.

Finding the method of financing becomes more attractive and innovative where almost majority of the management background researchers are aggressively discussed and proposed models of cash Waqf by using various methods. Most of the studies focused on cash Waqf because it claims to be more flexible and easy to use for developing Waqf project compare to fixed assets contribution. For example, Sadeq (2002) proposed a model of financing which is based on issuing Waqf certificate by Waqf institution. The mechanism of this model is as follows: the relevant body or institution will plan to build a project for the purpose of eradiate of poverty and social economic development. Then, this project is directed to Waqf administrative body (WAB) and WAB will introduce the project to the public and invite the public to donate cash for financing the project. The cash Waqf is raised by issuing Waqf certificate of a different denomination. The purpose of this model is to collect the fund from the public in a collective way and develop the project.

Cizakca (2004) and El-Gari (2004) proposed a model that based on the concept of cash Waqf. This concept is useful especially to provide a loan to microfinance. The researchers suggest establishing a non-profit financial institution that based on Qard Hassan which mean give a free interest-based loan. They say that the capital to setup the Bank is generated from the wealthy Muslim people. Similarly, Mohsin (2008) proposed to setup financial institution based on Waqf which will act as an Islamic Bank. The purpose is to generate Cash Waqf where the donor can deposit cash Waqf at the institution. This institution is basically to finance entrepreneur through Islamic mode of finance. Furthermore, the proposed model is basically to assist the projects in term of financial and the financial Waqf institution act as the trustee of the cash Waqf. 
Habib (2004) highlights the operational format of Sukuk Al Intifa'a with an illustrated example of King Abdel Aziz Waqf (KAAW) in Mecca. KAAW is a trustee that leases a piece of land at the centre of Mecca to the Bin Laden Group under the contract of Build-Operate-Transfer (BOT) for 28 years. In return, the group should build Zam Zam Tower which consists of the shopping complex, tower and hotels. Bin Laden Group subcontracts the construction of the tower to Kuwait Real Estate Company (Manshaat) which undertakes to finance the operation and operate it for 24 years. At the same time, the whole project will be transferred back to Bin Laden Group after getting an expected return of $26 \%$ per annum which is derived from the difference between the rentals rates received from Sukuk holder and the rate paid to Bin Laden Group. The Manshaat Company issued \$390 Million Sukuk Al Intifa'a for 24 years. This is to raise fund from investor to finance the construction of the project where the Sukuk holder will have the right to lease or utilize the specific unit of the tower for the period of 24 years. The advantage of this model of financing is after 28 years both the Waqf land and projects that development on the Waqf lands will be transferred to KAAW. Hence, later KAAW will fully manage the project and the return generated from the project will be used to support the social development. This type of financing is applicable for commercial development only because of the private participation which needs a payback return to cover their constructed cost.

Mohammad (2008) focused on the issue of idle, underdeveloped and underperforming Waqf lands. The author believes that Waqf institution should be independent and self-reliant which should have income generating Waqf land. Therefore, this paper proposes a framework for the marketability of Waqf properties as permitted by Islamic law and is achievable through the reformed concepts of Malaysian Land Administration system and its components. The author proposed to use (1) sale and purchase market for properties held as investment assets and that purchased through the income of the capital of Waqf; (2) leasing market, whereby long-term leases, equivalent to that leasehold alienation.

Jalil and Ramli (2008) proposed to use cash and e-Waqf, Waqf share and issuing Sukuk to generate fund accumulation for the Waqf construction project. The findings suggest several methods and structures of Waqf instrument for the future development which will be significant for those institutions that have planned to apply this concept in the nearest future. The method of issuing Sukuk also suggested by Sabit (2009) who proposes the best method of financing for the development of Waqf properties by using in-housing financing method and securitization. In-house financing is comprised of obtaining advanced rentals under the concept of Hikr, Ijarah, Istibdal, and cash Waqf. While securitization is 
such as equity participation (including Saham Waqf) and Sukuk. This paper explored the viability of securitization of the project, in-housing lump sum financing by way of long-term leases, substitution of land with cash (istibdal) Waqf shares, cash Waqf, usufruct Waqf and Waqf amalgamated development fund. Each of the instruments has its own advantages, but, if one has prioritized, preference should be given to cash Waqf. This is because of the ease of attracting the cash Waqf and its liquidity makes it the best choice for financing Waqf development project.

Tohirin (2010) discusses the cash Waqf model in relation to the empowerment of small businesses. The researcher proposed to establish Waqf institution under Islamic public finance. This institution will be responsible to generate cash Waqf from the society and provide financing for small-medium enterprise (SME). This enables SME to run and expand their business venture through the partnership with cash Waqf institution via profit loss sharing contract. Affandi and Nufus (2010) proposed to use cash Waqf to overcome the inability of government in providing prosperity for Indonesian society. The research suggests establishing Indonesian Waqf Deposit (IWD) as a representative of cash Waqf in Indonesia and focused on how IWD should channel their cash Waqf fund and available amount of cash Waqf toward the productive sector. This study found that the collection of cash Waqf in Indonesia is still far from the expectation and the sector that become most concerning of the people of Indonesia is the rehabilitation of poor family.

Hassan and Shahid (2010) study argue that is a need to introduce stakeholders' principle into the body of the institution of Waqf. The professional business management technique will undoubtedly create many positive opportunities for quality improvement of the institutions of Waqf and internal delegation of responsibility. For developing the vast under-used properties of the Waqf, this paper considers that, if institutions Waqf is to fulfil its social purpose, there is needed to create sources of funding for reconstruction of Waqf building by creating cash Waqf fund and by issuing Musharakah Sukuk. The returns from this initiative will be significant and more beneficiaries will be benefited.

Ahmad and Muhamed (2011) discussed the current state of Waqf development in Malaysia. The authors find that the Waqf institution does not have the capacity to develop Waqf properties due to lack of fund. This study attempts to examine steps and fund that has been allocated for the development of Waqf assets especially land and further evaluate its potential in developing Muslim's economy. This study employed descriptive analysis on the practice of JAWHAR and MAIN (SIRCs) as two leading institutions responsible for managing Waqf assets. The 
finding shows that Waqf fund has been allocated and being professional and there was also a special allocation for Waqf in RMK-9, RMK-1- and budget 2010. A special programme such as Waqf market for the people was also being implemented for ensuring the role of Waqf institution in economic development.

Alias (2012) in her conceptual paper discussed the application of certain venture capital strategies in both the investment and spending decisions of cash Waqf. In its investment decision, the cash Waqf might utilize some of the tools employed by venture capital firms for choosing its investment and for mitigating risk. She also mentioned that a possibility for the cash Waqf to consider certain venture capital opportunities as an alternative assets class in which to invest a portion of its corpus. In its spending decisions, the cash Waqf may choose its beneficiaries in much same way as venture capital firm would choose its investee; that is by putting together a port together a portfolio of non-profit organizations (NPOs) with proven track records for delivering social result and which is seeking to grow their organization to achieve financial sustainability. Therefore, she proposes an Enterprise Waqf Fund model that combines the cash Waqf model with the relevant concept from venture capital to enhance the dynamism of cash Waqf.

The above past studies discussion focused on the issues of management that comprises of mode of financing (Sadeq A. , 2002; Cizakca, 2004; Mohsin, 2008; Jalil and Ramli, 2008; Sabit, 2009; Tohirin, 2010; Lahsasna, 2010; Affandi and Nufus, 2010; Hassan and Shahid, 2010; Chowdhury, Ghazali, and Ibrahim, 2011; and Alias, 2012), introducing new independent Waqf body (El-Gari, 2004; Mohsin, 2005; Mohsin, 2008; Karim, 2008) and new financial method to develop Waqf project based on Sukuk (bond), ijarah (leasing), built-operate-transfer (BOT) (Ahmed H., 2004; Sabit, 2008; Sabit, 2009).

\subsection{Waqf Based Models}

This section highlights the development of projects that based on waqf in Muslim countries. These examples of the project will be the evidence for the present society toward Waqf contribution in the past and benefit the beneficiaries. The following sections highlight among the available models that develop based on Waqf contribution.

\subsubsection{Waqf Based Models In Education Sector}

Islam through its history provided a great attention to education as a basic component that to establish a learned society and great civilization. The Holy Qur'an in several verses has emphasized the importance of learning as a unique 
way to the existence of the Creator, Allah SWT. Even, the first Surah that read by Prophet Muhammad (PBUH) is Iqra means to read. This shows that the important and recognition of education in Islam.

Education is one of the main aims for Waqf development where the large portion of Waqf resources was allocated to build educational infrastructure such as school, libraries, and also providing the operational expenses such as lecturer's salaries and other. In this regard, the section highlights on Waqf Based model that develop for the education sector.

\subsubsection{Al-Azhar University, Kaherah}

Al-Azhar University is the oldest Islamic university in the world that established in year 359 Hijrah. The founder of this university is Jauhar As-Siqali who is a chief soldier during the era of Khalifah al-Muiz Lidiniah al-Fatimi. Then, during the era of Khalifah Fatimiyyah, al-Aziz Bi Allah is the man who established the Waqf system and he bought business warehouses and plantation for financing the University. He made the university is fully finance based on Waqf system. Then, the sixth Khalifah of Fatimiyyah, al-Hakim Bi Amr Allah was responsible for improving the education system become systematic. He improved the Waqf system by establishing new Waqf institution that called Dar al-Qurb or Dar alKharq al-Jadidah. This Waqf institution is financing the various academic activities including the al-Azhar and Majid Jami al-Rasyidah (Shuib, 1995). University AlAzhar has contributed significant benefit to Islamic world especially to produce great Islamic scholar, established special minister for Waqf, assist the Egypt country during the recession and liberalise the education system.

\subsubsection{The King Saud University Awqaf}

The Awqaf of King Saud University (KSU) is the largest university in the Kingdom of Saudi Arabia. The university is expected to generate an annual income of about four Billion. The university structures are unique where it has nine towers and each of the towers contains hotels, conference halls, commercial center and parking. The project amounts to 25 billion Saudi Riyals. The rector of the university says that most towers were devoted to pious businessmen, whereas the university' endowment administration took the responsibility to transform them into a productive investment which consists of flats, hotels and offices for rent. Ten percent of the revenues generated from the towers will be channelled to orphans and widows that enrolled in the university and the rest goes to finance the scientific research. 


\subsubsection{Madrasah Nizamiyh, Baghdad}

Madrasah Nizamiyyah is an academic institution that finance based on Waqf. The sole trustee of this institution is by Nizamul Mul and he managed the institution on its own. Nizamul Mulk is a respected individual that initiated the Waqf based institution in Bagdad and he had builds many schools and provide with the complete necessity of school resources such as a teacher, financial assistance and books. Nizamul Mulk not only focused on the developing of school building but he also creates fund worth for 600,000 dinars a year to pay the Islamic scholars, teachers and students. However, this Madrasah no longer active because of the Mongol empire attacked.

\subsubsection{Madrasah Al-Junied, Singapore}

Madrasah Al-Junied is another example of an academic institution that fully finances by Waqf fund. The Waqf asset is from Pengiran al-Syarif Syed Omar Bin Ali al-Juneid who initially purposes the Waqf asset is for cemetery purpose (Junid, 2004). However, the English government during time does not permit to use the land for the cemetery and then the grandchildren of al-Junied family, al-Salih Syed Abdul Rahman bin Junied bin Omar al-Juneid has proposed some methods of development to the authority. Then, the authority permits them to develop academic institution on the Waqf land (Junid, 1995).

\subsubsection{Waqf Based Academic Institution In Western Country}

There are several established academic institutions in Western countries that are based on Waqf system. For example, Oxford and Harvard University are among the universities that established by using Waqf system. In America, the Waqf system created in form of land-grant means gift of real estate by the government to some private authorities. This land-grant is gifted to several private authorities who responded to develop academic institutions, which still active until present. Foundations like Rockefeller, Ford Kennedy are among the foundations that have contributed to the development of Waqf system in America. In western countries, Waqf system is defined as Endowment fund or foundation. The creation of this system has a significant contribution to the academic sector in America, which Harvard University is in top 5 ranking of the best university in the world. Oxford University also established based on foundation fund in the year 1096 and today it is in top 5 ranking of the best university in the world. Oxford University is funded by several of bodies such as foundation, Trust Fund and others.

Wafa (2012) says that in the year 2003, 10 largest universities in US and UK, each having Endowment USD 74.74.24 billion and USD7.268 billion. Oxford and Cambridge then each had about USD 3.2 billion. University of Texas (2000) had 
US\$ 8.4 billion and Yale University with US\$7.4 billion. Harvard University in the year 2000 had funds totalling US\$ 19.2 billion, but in 2008 has USD 36 billion comprising of about 11,000 individual endowed funds. To raise such large funds, Harvard University spent $\$ 35$ million on fundraising and raised $\$ 427$ million. The development office has 250 employees, aided by 4,000 alumni volunteers. The Harvard Management company, a subsidiary of the university, is responsible for managing the endowment assets. Overall, by the year 2000, endowment funds in multiple sectors had reached a staggering value of USD2 trillion, generating revenues of USD700 billion.

\subsubsection{Waqf Based Academic Institution In Malaysia}

The Waqf based institution in Malaysia is started from the evolution of Sekolah Pondok become Madrasah and then transform into Islamic religious schools. Following examples is the Waqf based model that available in Malaysia.

\subsubsection{Madrasah Al-Attas, Pahang}

Syed Hassan Bin Ahmad Al Attas is the first person who has contributed Waqf assets for the purpose of education in 1860 which a Madrasah was built on the Waqf land from al-Habib Hassan. The establishment of this Madrasah (School) is his objective to spread the teaching of Islamic teaching and Arabic language for the local people in Malaysia. However, this Madrasah could not sustain its operation due to financial constraint and the management of the Madrasah is handover to the state government of Pahang in 1966. The state government has changed the madrasah name to Sekolah Menengah Agama al-Attas. Later, Habib Hassan al-Attas migrate to Johor and he has established another Madrasah called al-Attas in the year 1913. The Madrasah is sustaining until today and manage by his decedent. A trustee called Majlis Trustee was established that responsible for managing the Waqf assets of Marhum Habib Hassan al-Attas. The Majlis also responsible to manage to develop and maintain the Waqf assets to benefit the society. The Madrasah become an important institution that has teachers from Yemen, Egypt and Indonesia. Most of the students have further their study at alAzhar University.

\subsubsection{Maktab Mahmud}

Maktab Mahmud another Waqf based academic institution in Kedah. This Maktab is established by al-Marhum DYMM Tunku Mahmud Ibnu Al-Marhum Tunku Ahmad Tajuddin Al-Mukarram Shah in 1936. The objectives of establishing this Maktab are to spread Islamic teaching, Arabic language learning centre, and also to produce Islamic scholars. The Maktab is using Al-Azhar model but the fund is generated from the state government of Kedah and the federal government. 
Maktab Mahmud has its own assets in term own Waqf lands. Furthermore, Maktab Mahmud also has many franchises such as in Langkawi and Yan.

\subsubsection{Sekolah Agama Arab Al-Masriyah, Bukit Mertajam}

This school was established in the year 1906 which based Waqf. Tuan Guru Hj. Salleh is the founder of the school who received his father in law support in term of land and other Muslim wealthy people support to build the school. This Waqf land is registered under Majlis Agama Islam Pulau Pinang (MAIPP). Al Masriyah school system is from kindergarten to secondary school. The school is systems are operating and have support from the Jemaah Lembaga Pengurusan Sekolah and also Jabatan Agama Islam Pulau Pinang.

\subsubsection{Madrasah Arabia, Kluang}

This Madrasah was built on Waqf land in 1946 during the colonial of British. The Madrasah was established by few Muslim leaders with the objectives to spread the soul of Islamic knowledge especially to the young generation in Kluang. The Madrasah later has been taken charge by Jabatan Agama Johor (JAJ) in 1959 and they change the Madrasah name to Sekolah Menengah Agama Kluang (Juffri, 2004). Many Muslim scholars were produced by this Madrasah such as Prod. Madya Sulaiman Yassin (UKM), Dr.Ismail Mustari (Ketua Jabatan DAkwah, UTM) and many more.

\subsubsection{IIUM Endowment Fund}

IIUM Endowment Fund (IEF) has been established in March 1999 with the initial funds of RM3.5 million provided by the Malaysian government to support the poor and needy students who are academically but incapable of financing the fees and the cost of living (Sulaiman, Adnan, \& Nor, 2009). Various methods were used to raise funds such as donation from individual, companies and organization. The instruments that used are such as Kafalah programme, RM1 Campaign and other. IEF owned Azman Hashim complex in Gombak campus which can accommodate many business entities. It is expected to generate an annual rental income of RM500, 000.00 which will be used to finance the students' needs.

\subsubsection{Al Bukhary University}

This university is based on the Waqf system of Tan Sri Syed Mokhtar Albukhary's business world. The university is in the city of Alor Setar, Kedah Darul Aman. The university is fully funded through the Albukhary Foundation. The university has no tuition fee charged and all the students received a full scholarship from the foundation. Up 80 percent of the students are international and balance 20 percent are Malaysia students. The priorities are given to the students who are poor, disadvantaged, underprivileged. Furthermore, the university encourages their student to undertake planned social and community engagement activities 
and these to motivate the student passion to serve and contribute to others. Today, the university has gained the recognition from the country and foreign countries.

\subsubsection{Awqaf Alternative Plan (AAP) Model}

The past history evidenced the contribution of waqf in the education system and some of the waqf based education systems are still active until today. Based on the positive impact of waqf system to education, thus, we intend to continue the efforts of expanding the contribution of waqf into the administration of education system. The present study aims to address the administrative problem faced by most of the public universities in Malaysia and/or any related education system in the world. As discuss in the introduction part, we intend to introduce AAP model to address the issue of wastage faced by public universities. The following Figure 1 demonstrates the modus operandi of the proposed model.

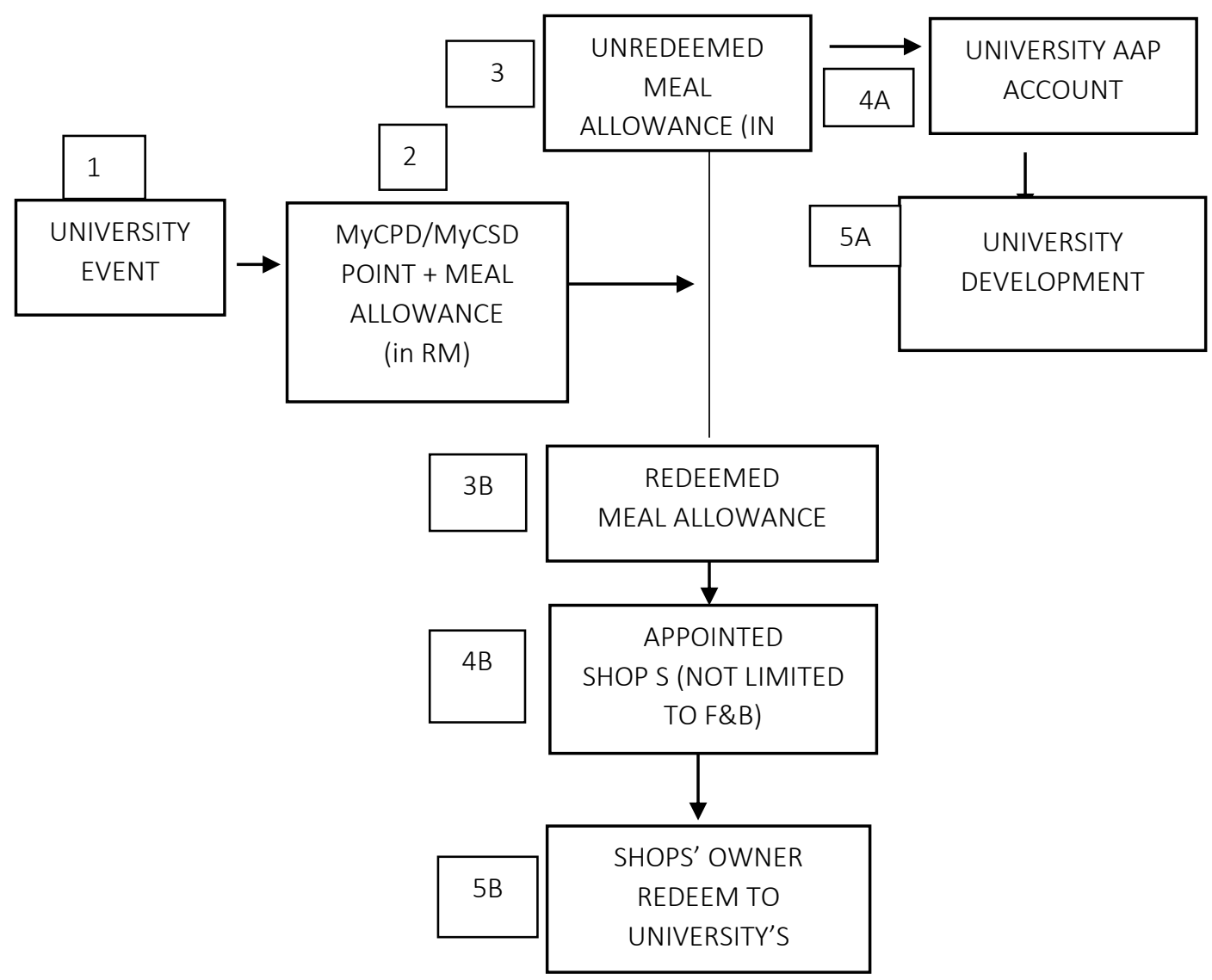

Figure 2.1

Awqaf Alternative Plan (AAP) Model

Source : Authors' Illustration 


\begin{tabular}{|c|l|}
\hline STAGE & \multicolumn{1}{c|}{ ACTION } \\
\hline 1 & Event organize by the university \\
\hline 2 & MyCPD + MyCSD + Meal Allowance \\
\hline 3A & Staff/Student who did not redeem the allowance within a month \\
\hline 4A & The allowance will be transferred into AAP Account \\
\hline 5A & $\begin{array}{l}\text { University will use the Cash Waqf for the development of the } \\
\text { campus }\end{array}$ \\
\hline 3B \& 4B & $\begin{array}{l}\text { The Staff/Student can redeem their allowance at the selected shops } \\
\text { (it's not limited to F \& B). }\end{array}$ \\
\hline 5B & $\begin{array}{l}\text { The shops' owner will redeem the allowances from the respective } \\
\text { Bursary. }\end{array}$ \\
\hline
\end{tabular}

Figure 1 shows the flow of the AAP model. In order to implement this system, thus, we proposed an application system which is developed in IOS and Android platforms. The following Figure 2 demonstrates the diagram of the proposed application.

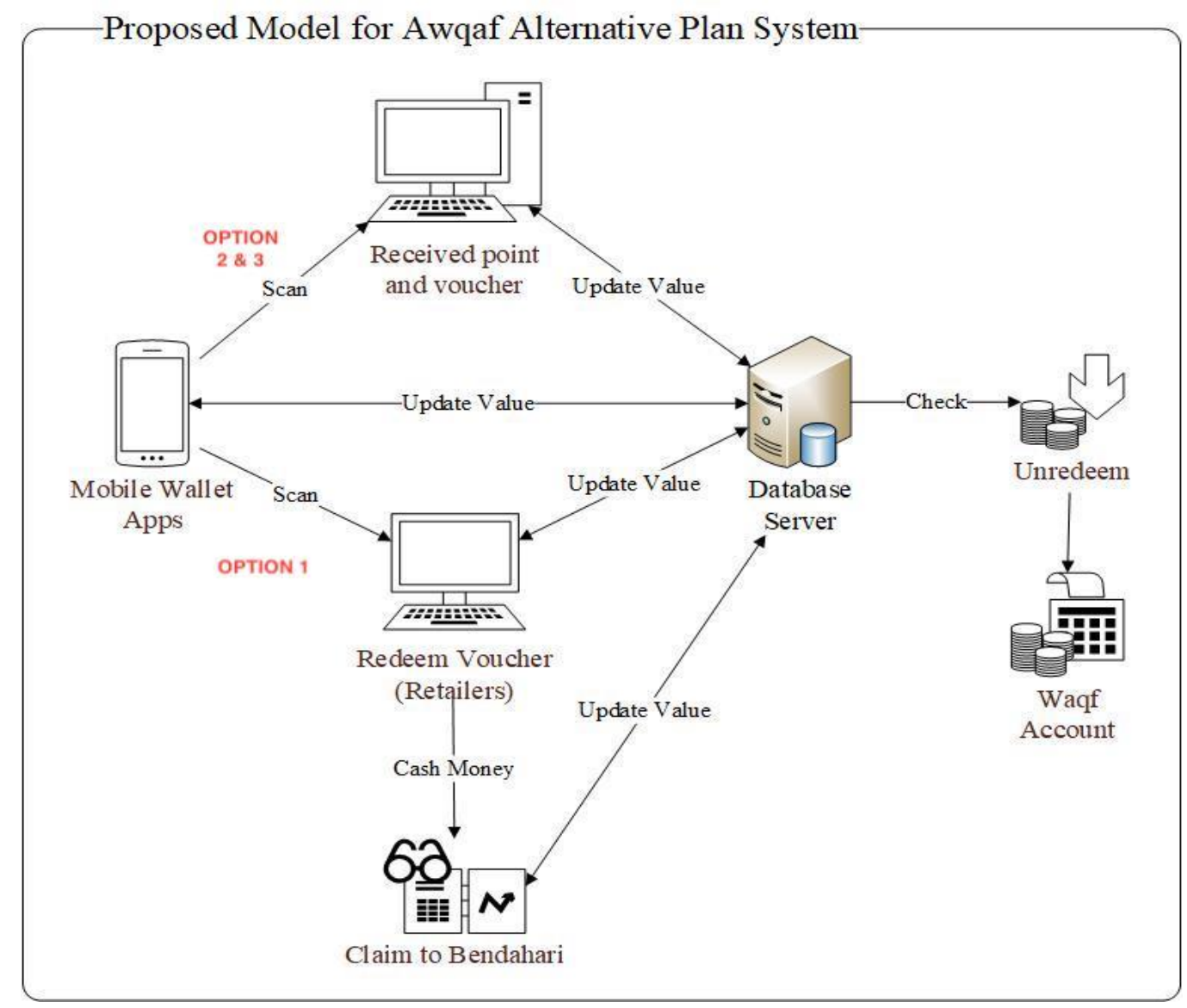

Figure 2.2

AAP Model under IOS and Android Platform 
Source : (Authors' Illustration)

\begin{tabular}{|c|c|}
\hline 1 & $\begin{array}{l}\text { The staffs/students have to download AAP model wallet apps which is } \\
\text { available for IOS and Android systems. }\end{array}$ \\
\hline 2 & The staffs/students require to Log-in using email and password \\
\hline 3 & $\begin{array}{l}\text { The staffs/students scan via APP wallet application to get University's activity } \\
\text { point and Meal Voucher allocated for the respective event. The information } \\
\text { of each staff/students is updated in the main database server }\end{array}$ \\
\hline 4 & The staffs/students have 3 OPTIONS; \\
\hline 4.1 & $\begin{array}{l}\text { Option 1: staffs/students can redeem voucher at the selected shop (F\&B, } \\
\text { stationaries) and every each transaction is updated in the main database } \\
\text { server. The retailers will claim accumulated amount of transaction to } \\
\text { university's Bursary }\end{array}$ \\
\hline 4.2 & $\begin{array}{l}\text { Option 2: staff/students can immediately donate the amount of voucher as a } \\
\text { cash Waqf. The main database server will update this transaction and the } \\
\text { amount cash Waqf is deposited into University 's Waqf account. }\end{array}$ \\
\hline 4.3 & $\begin{array}{l}\text { Option 3: The amount of voucher will be transferred automatically into } \\
\text { University's Waqf account if the staffs/students did not spend the voucher } \\
\text { within a month. }\end{array}$ \\
\hline
\end{tabular}

This system proposed the usage of QR Code technology for rewarding and redemption the vouchers to the students and staffs. The main advantage of a $Q R$ code is its versatility. QR codes can be used for anything and everything. They are also beneficial for both students, staff as well as selected retailers. In addition, QR code is cost-effective as it is easy to implement, paperless and does not require any paid licence.

\section{EXPECTED IMPLICATION OF THE AAP MODEL}

\subsection{Accurate Budget}

The AAP model is expected to calculate an accurate number of the participant based on the attendance and the cost to sponsor the $F \& B$ is paid according to the number of participants. This enhanced the cost saving and management of a public university in managing expenses. 


\subsection{Productivity And Freedom Of Choice}

The AAP model is expected to control the staff to use the allocated meal allowance during the lunch hour and they can choose any types of Food and Beverages that they prefer or the staff can redeem the allowance with stationaries.

\subsection{Waqf Account}

The AAP model is expected to create cash Waqf from the unredeemed allowance (WITHIN A MONTH OF PERIOD) and it is an income for the university to channel the accumulated cash Waqf fund for the development of the campus.

\subsection{Values and Character}

The AAP model is expected to promote sustainable values to the universities' financial management by eliminating wastage of food and, achieving accurate calculation method. Next, this model is able to promote positive character among the staff to focus on their work after any University's event instead of queuing up for food at the present system.

\section{CONCLUSION}

There are various ways to address the issue of reviving and rejuvenate the practised of waqf into the present days. Proposing a unique and sustainability model such as AAP model can contribute to solve various problem faced by management. This system has established during the era of Islam and it has significant contribution toward several sectors such as health, academic and others. Therefore, there is an urgent attention to Islamic countries leaders as well as Muslim societies to rejuvenate the role of Waqf in the present system which will sustain and prosper the future generation of a country. 


\section{REFERENCES}

Affandi.H and Nufus.D. (2010), "Analysis of Cash Waqf Return Fund Allocation in Indonesia: A Case Study in Indonesian Waqf Deposit". Available at http://www.ukm.my/hadhari/sites/default/files/prosiding/p7.pdf

Ahmad, S., \& Muhamed, N. D. (2011). Institusi Wakaf dan Pembangunan Ekonomi Negara: Kes Pembangunan Tanah Wakaf di Malaysia. PROSIDING PERKEM VI, JILID 1 (2011) 138 - 147, ISSN: 2231-962X.

Alias T.A. (2012). Venture Capital Strategies in Waqf Fund Investment and Spending", ISRA International Journal of Islamic Finance, Vol. 4, Issue 1.

Cizakca, M. (2004). Cash Waqf as Alternative to NBFIs Bank. International Seminar on Nonbank Financial Institution: Islamic Alternative. Kuala Lumpur: Islamic Research and Training Institution, Islamic Development Bank and Islamic Banking and Finance Institute Malaysia.

Elgari MA (2004). The Qard Hassan Bank. International Seminar on Nonbank Financial Institutions: Islamic Alternatives, March 1-3, 2004, Kuala Lumpur, jointly organized by Islamic Research and Training Institute, Islamic Development Bank and Islamic Banking and Finance Institute Malaysia

Habib Ahmed, Role of Zakah and Awqaf in Poverty Alleviation (Saudi Arabia: Islamic Development Bank Group Islamic Research \& Training Institute, Jeddah, 1st edn., 2004), 128.

Hassan, A. and Shahid, M.A. (2010), "Management and development of the awqaf assets", Paper Presented at the Seventh International Conference-The Tawhidi Epistemology: Zakat and Waqf Economy, Bangi.

Hoexter, M. (1998). Waqf Studies in the Twentieth Century: The State of the Art. Journal of the Economic and Social History of the Orient, 41, 474-495.

Jalil, Abdullaah \& Ramli, Ashraf Mohd, (2008). Waqf Instruments For Construction Contract: An Analysis Of Structure. Journal of Muamalat and Islamic Finance, 5(1).

Mohammad MTSH (2008). Sustaining the means of Sustainability: The need for accepting Wakaf (Waqf) assets in Malaysian property market. The 14th Annual Conference of the Pacific Rim Real Estate Society, January 20 - 23, 2008, Istana Hotel, Kuala Lumpur, Malaysia

Sabit, M. T. (2006). An Ideal Mechanism for the Development of Waqf Properties. Johor: Universiti Teknologi Malaysia Press, 2nd Edition.

Sabit, M. T. (2009). Alternative Development Financing Instruments For Waqf Properties. Malaysian Journal of Real Estate, Volume 4 No 2.

Sadeq, (2002) "Waqf, perpetual charity and poverty alleviation", International Journal of Social Economics, Vol. 29 Issue: 1/2, pp.135-151, https://doi.org/10.1108/03068290210413038 
Tohirin, Achmad. (2010), The Cash Waqf for Empowering the Small Businesses. Seventh International Conference - The Tawhidi Epistemology. Zakat and Waqf Economy, Bangi. 
This page is intentionally blank 